\title{
Cryopreservation Technique: a Powerful Tool for Long-term Preservation of Endangered Medicinal Plants
}

\section{Pushpa, Nidhi Didwania*}

Department of Biotechnology, Manav Rachna International Institute of Research Studies, Sector-43, Surajkund Road, Faridabad, Haryana, India

Key words: Germplasm, Vitrification, Genetic stability.

\section{Introduction:}

Globally, medicinally important plant species are the most precious sources for new plant-based products as well as herbal medicines (Chen et al., 2010, Hamilton, 2004; Chacko et al., 2010). The medicinal plant species use is mounting day by day in the whole world due to rising demand for herbal drugs, herbal products, and secondary metabolites that are present in them (Cole et al., 2007). By an estimation of IUCN and WWF, flowering plant species ranges between 50,750 and 80,000 used for medicinal purposes throughout the world. In the countries that are developing, up to $82-85 \%$ of people are completely reliant on medicinal plant-based medicines for primary healthcare whereas, in developed countries, only $22-26 \%$ of given medicines are the derivative of important species of medicinal plants (Hamilton, 2004). In Europe, there are more than 1200-1300 plants used as herbal drugs of that $95 \%$ are harvest byvaluable plant species.

In medical traditions, medicinally important plant species are the first source for herbal products/medicines.

\section{Abstract}

India is one of the harbour of richest biodiversity of plant species, which comprises of many medicinally rich plants. But, day by day the plant species are disappearing by overexploitation to meet the growing demand for plantbased medicines. The tools of biotechnology are signif icant for selection, development as well as conservation of valuable plants having medicinal value. The cryopreservation technique is one of the powerful biotechnological tools for the preservation of medicinal plants. This technique conserves the medicinal plants in liquid nitrogen at $-196^{\circ} \mathrm{C}$ for the long-term and provides a safe and inexpensive opportunity for the preservation of critically endangered plant species. Cryopreservation is a simple and reliable technique for the cryopreservation of medicinal plants as germplasm as well as the management of in vitro produced materials for the application of biotechnology. The new techniques of cryopreservation based on vitrification, are successfully applied of all explants such as temperate of medicinal plants and zygotic and somatic embryos of tropical species as well. Till date, various explants of endangered species have been used for their cryopreservation. The techniques of cryopreservation provide the genetic stability of various medicinal plants.

These medicinal plants are currently in use for various purposes such as pharmaceuticals, homemade remedies, preparation in dietary supplements, homeopathic medicines, in the preparation of medicinal and herbal teas, herbal cosmetics and other herbal product preparation (Tahtmouni et al., 2015). The plants especially flowering plant species which are nearly 60,950-90,460 classified as valuable species having medicinal properties (Sharma et al., 2010; Ozturk, 2012). There are about 6oo-120o taxa of plant species widely used as traditional medicine (Ozturk, 2012). About 490 plant species were reported as medicinal plants in Jordan that belong to 99 different families (Al- Oran, 2011).

\section{Some threats to Medicinal Plant Species:}

The medicinal plant resources are under threat by overharvesting, increasing demand for plant-based medicines and natural habitat destruction of wild resources. About 15,000 plant species are threatened with extinction by the overharvesting of plant resources and their natural habitat destruction (Bentley, 2010). With the 
Table 1:- List of some important medicinal plant species:

\begin{tabular}{|c|c|c|c|c|c|}
\hline \# & PlantSpecies & Family & Common Name & Explants & References \\
\hline 1 & Acorus calamus & Araceae & Sweetflag & Rhizometip \& Rhizome segments & Yadav et al.(2011) \\
\hline 2 & Ginkgo biloba & Ginkgoaceae & MaidenhairTree & Apical and nodal segments & Tommasi \& Scaramuzzi (2004) \\
\hline 3 & Stevia rebaudiana & Asteraceae & Sugarleaf & Apical \& nodal segments & Kumar \& Singh (2009) \\
\hline 5 & Celastrus paniculatus & Celastraceae & Black Oil Plant & Seeds, nodal segments \& shoot tip & Lal \& Singh (2010) \\
\hline 6 & Tinospora cordifolia & Meninspermaceae & Giloy & Nodal segments & Gururaj et al. (2007) \\
\hline 7 & Saussurea lappa & Compositae & Kuth & Shoot tip & Johnson et al. (2007) \\
\hline
\end{tabular}

Table 2: List of Some Critically Endangered Medicinal plant Species in India

\begin{tabular}{|c|c|c|c|c|}
\hline \# & Plant Species & Common/Hindi Name & Type & Medicinal Value \\
\hline 1 & Aconitum chasmanthum & Gaping monkshood/Meetha zahar & Perennial herb & $\begin{array}{l}\text { Analgesic, anodyne, diaphoretic, diuretic, } \\
\text { irritant and sedative }\end{array}$ \\
\hline 2 & Chlorophytum borivilianum & White gold/ Safedmusli & Tuberous herb & Diabetes, arthritis, natal \& post natal problems \\
\hline 3 & Gentiana kurroo & Himalayan Gentian/ Karu & Perennial herb & $\begin{array}{l}\text { Antiperiodic, expectorant, blood purifier } \\
\text { antithelmintic, stomachic \& carminative }\end{array}$ \\
\hline 4 & Gymnocladus assamicus & Minkling/ DaruHaridara & Deciduous tree & Curing swelling and abscesses \\
\hline 5 & Lilium polypyllum & White lily/ Ksirakakoli & Perennial herb & $\begin{array}{l}\text { Expectorant, astringent, aphrodisiac, } \\
\text { antipyretic and general debility }\end{array}$ \\
\hline 6 & Saussurea costus & Costus/ Kuth & Perennial herb & $\begin{array}{l}\text { Asthma, cough, gas, and severe intestinal } \\
\text { diseases such as dysentery and cholera }\end{array}$ \\
\hline 7 & Nardostachys jatamansi & Indian nard/ Balchchard & Perennial herb & $\begin{array}{l}\text { Controlling high palpitation of the heart, } \\
\text { antiseptic, treating epilepsy }\end{array}$ \\
\hline 8 & Commiphora wightii & Oleo gum/ Guggulu & Tree & Decrease cholesterol synthesis in the liver \\
\hline
\end{tabular}

increasing human population and plant-based drug consumption, 10-20 \% of their wild resources have already been nearly exhausted (Ross, 2005). Due to the accelerated loss of the plant's species and destruction of their natural habitat worldwide increased the risk of extinction of endangered medicinal plants, especially in India Nepal and Kenya (Hamilton, 2008), Tanzania (Zerabruk \& Yirga, 2012), China (Nalawade et al., 2003 and Heywood et al., 2003) and Uganda (Zerabruk \& Yirga, 2012).

\section{Need of Cryopreservation:}

The medicinal plant contains an effective bioactive compound that is currently used in the manufacturing of medicines against various diseases. As a consequence, species of medicinal plants have become rare, endangered and critically endangered due to the high consumption rate of plant-based medicine as a comparison to growing. So, the risk of plant material loss is increasing day by day. To compensate for those risks, cultures of the medicinal plant should be maintained or conserved for a long time by using a biotechnological tool i.e., cryopreservation.

Cryopreservation (long term preservation): it is described as the most potent tool for the long-term preservation of plant germplasm (Sakai \& Englemann, 2007). As a technique, followed by ultra-rapid freezing, cryopreservation is based on the eradication of all freezable water from tissues using physical or osmotic dehydration (Reed et al., 2004). As a result; removal of water comprises a backbone in preventing freezing injury and in retaining post-thaw viability (Gonzalez-Arnao \& Engelmann, 2006). During freezing, Crystallization is considered as the main factor affecting cell survival subjected to the technique of cryopreservation. During the warming procedure, ice crystals are formed, it becomes detrimental to cellular integrity. As plant material storage occurs at an ultra-low temperature, due to slow warming, the tendency for large ice crystals to grow becomes greater and to avoid thawing should be rapidly performed by placing the cryovials in a water bath at $37-40^{\circ} \mathrm{C}$ for a few minutes (Mazur, 2004). So, if post thawing is done rapidly, there will be insufficient time for de-vitrification and yet higher recovery rates will be achieved (Gonzalez-Arnao et al., 2008).

In terms of simplicity and the applicability to a wide range of genotypes, cryopreservation was always reported to be a reliable, safe and cost-effective method over most other conservation methods used for long term preservation of medicinal plants.

Principle of Cryopreservation: this technique is the storage of medicinal plant material at ultra-low temperature $\left(-196^{\circ} \mathrm{C}\right)$ that takes place in a cryogenic condition, in liquid nitrogen (Wen \& Wang, 2010). At this temperature, the plant cell ceased with all forms of metabolic activities and cellular divisions consequently, for an indef inite period stored plant material remain unaltered (Gonzalez-Arnao et al., 2008; Shatnawi et al., 2011).

Mechanism of Cryopreservation: this technique is based 
on the transfer of water from a liquid state to a solid-state that presents in the cells. Within the cells, salts and organic molecules are present which requires much lower temperature for freezing $\left(-68^{\circ} \mathrm{C}\right)$ in comparison to the freezing point of pure water $\left(0^{\circ} \mathrm{C}\right)$. After storing at ultra-low temperature, all the activities like metabolic and biological activities of plant tissues or cells almost come to halt. This technique involves the following steps:

\begin{tabular}{|l|c|c|}
\hline $\begin{array}{c}\text { Selection of } \\
\text { Material }\end{array}$ & $\begin{array}{c}\text { Addition of } \\
\text { Cryoprotectant }\end{array}$ & $\begin{array}{c}\text { Storage in } \\
\text { Liquid Nitrogen }\end{array}$ \\
\hline $\begin{array}{c}\text { Regeneration } \\
\text { of Plants }\end{array}$ & Cryopreservation & Freezing \\
\hline $\begin{array}{c}\text { Measurement } \\
\text { of Viability }\end{array}$ & Thawing & $\begin{array}{c}\text { Washing and } \\
\text { Reculturing }\end{array}$ \\
\hline
\end{tabular}

Cryopreservation Techniques:

Recently, most of the cryopreservation researches had focused on the development of simple and reliable techniques and would apply to various types of plant material such as shoot tips, cultured cells and somatic embryos (Sakai \& Englemann, 2007). This had outcome different procedures for cryopreservation (long term preservation), like vitrification, encapsulationvitrification, encapsulation-dehydration, and dropletvitrification (Engelmann, 2004).

Vitrification: it is a new cryopreservation technique that defined as supercooling a highly concentrated cryoprotectant at ultra-low temperature and without undergoing crystallization, the cryoprotectant will solidify into a metastable glass state (Sakai \& Englemann, 2007). It is a safe and effective freeze-avoidance mechanism. It will stop all the chemical reactions when the glass state is attained which requires molecular diffusion and yet will lead to metabolic inactivity as well as stability over time. This technique of cryopreservation is based on three major phases i.e. loading phase, dehydration (with the highly concentrated vitrif ication solutions) and unloading phase. In loading phase (first-phase) samples are exposed to diluted vitrification solutions or cryoprotectants, in a second phase (dehydration), before being plugged in LN, the samples are dehydrated by a highly concentrated vitrification solution. In the unloading phase (third phase), after rapid thawing, the vitrification solution is drained out of the cryovials and then replaced routinely with $1.2 \mathrm{M}$ sucrose for the time of 10-2omin (Shibli et al., 2006; Shatnawi et al., 2011). Plant vitrification solution (PVS2) is an aqueous cryoprotectant solution in which living material from plant resources can be cooled without appreciable ice formation either extra or intracellularly (Kim et al., 2006). At a proper concentration, cryoprotectants must be optimized to become non-toxic. It should be readily miscible and with a high ability to penetrate medicinal plant cells rapidly (Shibli et al., 2006). In most vitrification protocols, plant vitrification solution
2 (PVS2) is widely used and it is formed by a mixture of cryoprotectants includes $30 \% \mathrm{w} / \mathrm{w}$ glycerol, $15 \% \mathrm{w} / \mathrm{w}$ ethylene glycol, $15 \% \mathrm{w} / \mathrm{w}$ dimethyl sulfoxide DMSO in MS medium supplemented with $0.4 \mathrm{M}$ sucrose (Sakai \& Engelmann, 2007; Shatnawi et al., 2004; Rabba'a et al., 2012). In Jordan several species were reported as cryopreserved successfully using vitrification technique such as, Teucrium polium (Rabba'a et al., 2012), Capparis spiunosa (Shatnawi, 2011), Phoenix dactylifera (Subaih, et al., 2007), Artemisia herba-alba (Sharaf et al., 2012)and Achillea fragrantissima L. (Younis, 2012).

Encapsulation/dehydration: Fabre \& Dereuddre (1990) first reported the encapsulation/dehydration method for the conservation of medicinal plants. In this technique, first pre-culture of shoot tips or embryo with sucrose medium (0.3-0.6 M) for 1-3 days, then pre-culture was encapsulated into the beads of alginate and also treated with $0.8 \mathrm{M}$ sucrose solution (highly concentrated) for approx. 16 hours. In the samples, dehydration tolerance was induced by treatments. After completion of the pretreatment procedure, on the silica gel, samples are dehydrated to reach their optimal hydration levels. During the drying process, the molarity of sucrose increases and reaches a saturation point of sucrose solution, resulting in glass transition during cooling to $-196^{\circ} \mathrm{C}$. In this technique, no other cryoprotectants are required and have been successfully applied to various types of medicinal plant species. Encapsulation/ dehydration technique is very simple, user-friendly and eff icient (Matsumoto, 2017).

Droplet-vitrification: this cryopreservation technique was first developed by Kartha et al. (1982) and then modified by Leunufna \& Keller (2003). In this technique, medicinal plant material is treated with vitrification solution i.e., $\mathrm{PVS}_{2}$ and then shoot tips are individually inserted into the droplets of the PVS2 solution, that is placed on the aluminum foil. After that, the material is directly dipped in liquid nitrogen (LN). This method was applied to some species of plants such as T.moroderi, T.longicaulis, and Thymus vulgaris and then reported as a successful method (Tahtamouni et al., 2015). The method of cryopreservation has been successfully applied in the preservation of a shoot tip of garlic (Kim et al., 2009). The main application of this droplet-vitrification method is the possibility of achieving very high cooling as well as warming rates in the presence of very low medium (cryoprotective medium) in which the shoot tips of medicinal plants are placed (Matsumoto, 2017).

Encapsulation-vitrification: in this technique, plant material is encapsulated with the beads of alginate and then treated with the PVS2 solution which is used in vitrif ication technique, for this dehydration process (by air and silica gel) is not required (Younis, 2012). The technique allows the explants to freeze within a short time period (Tahtamouni 
et al., 2015), easy to handle plant material, as well as a large number of the specimen, are easily treated simultaneously. Furthermore, the method is also suitable for small samples like callus, hairy roots as well as suspension cultures(Matsumoto, 2017).

\section{Genetic stability of Cryopreserved Plants:}

The aim of cryopreservation techniques is to maintain the genetic stability of medicinally important plant material besides conservation. Ones the explant is stored by cryogenically that ceased the metabolic activities theoretically and after rewarming from cryopreservation, consequently, the material of conserved plant is expected to be of true type (Kaczmarczyk et al., 2012). So, the validity of this cryopreservation method is only achieved if the genetic stability of plant material is not changed after exposure to liquid nitrogen (Zarghami et al., 2008). Unlike genetic changes; the original sequence of DNA is not altered by epigenetic modifications as these modifications are usually featured with alterations in DNA methylation (Smulders \& Klerk, 2011). Thesealterations may beaffecting the gene transcription; epigenetic modifications are usually temporary and plants might get back to their normal phenotypes relatively easily (Smulders \& Klerk, 2011). Examples of different genotypes that were reported with epigenetic variation after cryopreservation are Carica papaya (Kaity et al., 2008, 2009) and Ribes (Johnston et al., 2009). For the assessment of the genetic stability of plant material, several molecular markers have been used (Harding, 2004). The two most popular markers used in this domain are amplif ied fragment length polymorphisms (AFLP) and randomly amplified polymorphic DNA (RAPD) (Micula et al., 2011). However, sometimes more than one molecular marker was used i.e. AMP (amplified DNA methylation polymorphism) and RAF (randomly amplif ied DNA fingerprinting) for Carica papaya (Kaity et al., 2008; 2009) and SSR (simple sequence repeats) for (Quercus suber L.) (Fernandes et al., 2008)

\section{Conclusion:}

The medicinally important plant species became the main constituents for medicines, food as well as other phytoindustries. Meanwhile, due to over-harvesting, these plants are endangered due to the increasing use in medicine, food and the beverages industry. So, conservation of these natural plant resources is of high priority. The biotechnological tool i.e., cryopreservation conserves the plant resources for the long term without any change in their genetic stability. It consists of a conservation technique which is vitrification, simple, applicable to a wide range of genotypes and also able to maintain the genetic stability of the stored medicinal plant material.

\section{References:}

Al-Oran, S. (2011): Conservation of medicinal plants in Ajlun woodland /Jordan. L.Med. Plants Res., 5(24):5857-5862,

Chacko, S.M., Thambi, P.T., Kuttan,R. \& Nishigaki, I. (2010): Beneficial effects of green tea: a literature review. Chin. Med., 5: 13.

Chen, S.L., Yao, H., Han, J.P., Liu, C., Song, J.Y., Shi, L.C., Zhu, Y.J., Ma, X.Y., Gao, T., Pang, X.H., Luo, K., Li, Y., Li, X.W., Jia, X.C., Lin, Y.L. \& Leon, C. (2010). Validation of the ITS2 region as a novel DNA barcode for identifying medicinal plant species.PLoSONE., 5: e8613.

Cole, I.B., Saxena, P.K. \& Murch, S.J. (2007): Medicinal biotechnology in the genus Scutellaria. In Vitro Cell. Dev. Plant., 43(4):318-327.

Engelmann, F. (2004): Plant cryopreservation: progress and prospects. In Vitro Cell. Dev. Biology-Plant, 40(5): 427-433.

Fabre, J, \& Dereuddre, J. (1990): Encapsulation-dehydration: A new approach to cryopreservation of Solanum shoot tips. CryoLett., 11:413-426.

Fernandes, P., Rodregus, E., Pinto, G., Roldan-Ruiz, I., Deloose, M. \& Santos, C. (2008): Cryopreservation of Quercussuber somatic embryos by encapsulation-dehydration and evaluation of genetic stability. Tree Physiol., 28(12):1841-1850.

Gonzalez-Arnao, M.T. \& Engelmann,F. (2006): Cryopreservation of plant germplasm using the encapsulation-dehydration technique: Review and case study on sugarcane. Cryolett., 27(3):155-168.

Gonzalez-Arnao, M.T., William, A.P., Roca, R., Escobar, R.H. \& Engelmann,F. (2008): Development and large scale application of cryopreservation techniques for shoot and somatic embryo cultures of tropical crops. Plant Cell Tissue Organ Cul., 92(1):1-13.

Gururaj, H.B., Giridhar, P. \& Ravishankar, G.A. (2007): Micropropagation of Tinospora cordifolia (Willd.) Miers ex Hook. F \& Thoms: a multipurpose medicinal plant. $\underline{\text { Current }}$ Sci., 92(1):23-25.

Hamilton, A.C. (2004): Medicinal plants, conservation and livelihoods. Biodivers. Conserv., 13: 1477517.

Hamilton, A.C. (2008). Medicinal plants in conservation and development: case studies and lessons learned. In: Kala CP, (ed.) Medicinal Plants in Conservation and Development. Pub. by: Plantlife International Publisher, Salisbury.

Harding, K. (2004): Genetic integrity of cryopreserved plant cells: a review. Cryo. Lett., 25(1):3-22.

Johnson, R.B., Onwuegbuzie, A.J. \& Turner, L.A. (2007): Toward a Definition of Mixed Methods Research. J. Mix. Meth. Res., 1(2):112-133.

Johnston, J.W., Benson, E. \& Harding, K. (2009): Cryopreservation induces temporal DNA methylation epigenetic changes and differential transcriptional activity in Ribesgermplasm. Plant Physiol. Biochem., 47(2):123-131.

Kaczmarczyk, A., Funnekotter, B., Menon, A., Phang, P.Y., AlHanbali, A., Bunn, E. \& Mancera, R.L. (2012): Current issues in plant cryopreservation, (Ch 14.) pp: 418-430. In: Current Frontiers in Cryobiology. Pub. by: ALCOA of Australia Ltd and BHP Billiton WorsleyAlumina Pty Ltd. Australia.

Kaity, A., Ashmore, S.E. \& Drew, R.A. (2009): Field performance evaluation and genetic integrity assessment of cryopreserved Papaya clones. Plant Cell Rep., 28(9):1421-1430.

Kaity, A., Ashmore, S.E., Drew, R.A. \& Dulloo, M.E. (2008): Assessment of genetic and epigenetic changes following 
cryopreservation in Papaya. Plant Cell Rep., 27(9):1529-1539.

Kartha, K.K., Leung, N.L. \& Mroginski, L.A. (1982): In vitro growth responses and plant regeneration from cryopreserved meristems of cassava (Manihot esculenta Crantz). Zeitschrift für Pflanzenphysiologie, 107(2):133-140.

Kim, H., Yoon, J., Kim, J., Engelmann, F. \& Cho, E. (2006): Thermal analysis of garlic (Allium sativum) shoot tips during a vitrification procedure. Cryo. Lett., 26(1):33-44.

Kim, H.H., Lee, Y.G., Park, S.U., Lee, S.C., Baek, H.J., Cho, E.G. \& Engelmann, F. (2009): Development of alternative loading solutions in droplet-vitrification procedures. Cryo. Lett., 30(4): 291-299.

Kumar, S. \& Singh, N. (2009): In vitro propagation of Stevia rebaudiana Bertoni: an important medicinal sweet herb. Environ. Ecol., 27(IA):459-46.

Lal, D. \& Singh, N. (2010): Mass multiplication of Celastrus paniculatusWilld: an important medicinal plant under in vitro conditions via nodal segment. Int. J. Biodivers. Conserv., 2(6):140-145.

Leunufna, S. \& Keller, E.R.J. (2003): Investigating a new cryopreservation protocol for yam (Discorea spp.). Plant Cell Rep., 21(12):1159-1166.

Matsumoto,T. (2017): Cryopreservation of plant genetic resources: conventional and new methods. Agricul. Sci., 5:13-20.

Mazur, P. (2004): Principles of Cryobiology, pp: 5-55. In: Fuller BJ, Lane N, Benson EE (eds): Life in the Frozen State Pub. by: CRC Press.

Mikula, A., Tomiczak, K. \& Rybczyniski, J.J. (2011). Cryopreservation enhances embryogenic capacity of Gentiana cruciata (L.) suspension culture and maintains epigenetic uniformity of regenerants. Plant Cell Rep., 30(4): 565-574.

Mohapatra, H.P. \& Rath, S.P. (2005): In vitro studies of Bacopa monnieri an important medicinal plant with reference to its biochemical variations. Indian JExp Biol., 43(4):373-6.

Ozturk, M., Altundag, E. \& Gucel, S. (2012): Medicinal and aromatic plants (Turky). Ethnopharmacology, 1-52.

Rabba'a, M., Shibli, R.A. \& Shatnawi, M.A. (2012). In Vitro medium term conservation of felty germander (Teucrium polium L.) micro-shoots. Jordan J. Agricul. Sci., 8(4):523-544.

Reed, B.M., Engelmann, F., Dulloo, M.E. \& Engels, J.M.M. (2004): Technical guidelines for the management of field and in vitro germplasm collections.Pub. by: International Plant Genetic Resources Institute, IPGRI. Rome, Italy.

Ross, I.A. (2005): Medicinal plants of the world: chemical constituents, traditional and modern medicinal uses. Pub. by: Humana Press Inc.,New Jersey.

Sakai, A. \& Engelmann, F. (2007): Vitrification, encapsulationvitrification and droplet vitrification: A review. Cryo. Lett., 28(3):151-72.
Sharaf, S.A., Shibli, R.A., Kasrawi, M.A. \& Baghdadi, S.H. (2012): Cryopreservation of wild shih (Artemisia herba-alba) Asso. shoot-tips by encapsulation-dehydration and encapsulationvitrif ication. Plant Cell Tiss. Organ Cul., 108(3):437-444.

Shatnawi, M.A., Anfoka, G., Shibli, R.A., Al-Mazra'awi, M.S., Shahrour, W. \& Arebiat, A. (2011): Clonal propagation and cryogenic storage of virus free grapevines (Vitis vinefera L.) via meristem culture. Tur. J. Agricul. Forest., 35(2):173-184.

Shatnawi, M.A., Johnson, K.A. \& Torpy, F.R. (2004): In vitro propagation and cryostorage of Syzygium francissi (myrtaceae) by the encapsulation dehydration method. $\underline{I n}$ Vitro Cell. Develop. Biol.-Plant, 40(4):403407.

Shibli, R., Shatnawi, M., Subaih, W. \& Ajlouni, M. (2006): In vitro conservation and cryopreservation of plant genetic resources: A review. World J. Agricul. Sci., 2:372-382.

Singh, N., Kaur, A. \& Yadav, K. (2010): A reliable in vitro protocol for rapid mass propagation of Sapindus mukorossi Gaertn. NatSci., 8(10):41-47.

Smulders, M.J.M.\& Klerk, G.J. (2011): Epigenetics in plant tissue culture. Plant Growth Regul., 63(2):137-146.

Subaih, W., Shatnawi, M.A. \& Shibli, R.A. (2007): Cryopreservation of date palm (Phoenix dactylifera) embryogenic callus by encapsulation-dehydration, vitrification and encapsulation-vitrification. Jordan J. Agricul. Sci., 3:16-171.

Tahtamouni, R.W., Shibli, R.A., Al- Abdallat, A.M., Al-Qudah, T.S., Younis, L., Al-Baba, H. \& Al- Ruwaiei, H. (2015): In Vitro Conservation and Cryopreservation of Medicinal and Aromatic Plants: A Review. Jordan J. Agricul. Sci., 11(1).

Tommasi, F. \& Scaramuzzi, F. (2004): In vitro propagation of Ginkgo biloba by using various bud cultures. Biol.Plantarum, 48 (2): 297-300.

Wen, B. \& Wang, R.L. (2010): Pretreatment incubation for culture and cryopreservation of Sabal embryos. Plant Cell Tissue Organ Cul., 102: 237-243.

Yadav, K., Singh, N. \& Aggarwal, A. (2011): Influence of arbuscular mycorrhizal (AM) fungi on survival and development of micropropagated Acorus calamus L. during acclimatization. Bulgarian J. Agricul. Sci., 7(3):775-781.

Younis, L.S. (2012): In vitro multiplication and conservation of Acheillea fragrantissima Foorssk SCH. BIP. M. Sc. Thesis. The University of Jordan, Amman, Jordan.

Zarghami, R., Pirseyedi, S.M., Hasrak, S.H. \& Pakdaman, B.S. (2008): Evaluation of genetic stability in cryopreserved Solanum tuberosum. Afr. J. Biotechnol., 7:2798-2802.

Zerabruk, S. \& Yirga, G. (2012): Traditional knowledge of medicinal plants in Gindeberet district, Western Ethiopia. $\underline{S}$ Afr.J. Bot., 78:16-59. 